\title{
Problem intuicije moralnosti u filozofiji Johna Rawlsa
}

Marko Jakić*

marko.jakic84@gmail.com
UDK: 1 Rawls, J.

17.032.1

Izvorni znanstveni rad / Original scientific paper

Primljeno: 30. studenog 2017.

Prihvaćeno: 7. ožujka 2018.

Članak se bavi mogućom proturječnošću stajališta o intuiciji moralnosti u filozofiji Johna Rawlsa. U uvodnom dijelu kritički su navedena relevantna suvremena teorijska stajališta o problemu intuicije moralnosti, s posebnim obzirom na neposredni intuicionizam, relativizam i doktrinarni moralni pluralizam. Rawlsova teorijska pozicija izlučena je u središnjem dijelu članka zajedno s potkrjepljujućim argumentima u prilog tvrdnji o njegovoj teorijskoj poziciji kao fundacionalističkom posrednom intuicionizmu. Analizirani su dodatni argumenti u prilog Rawlsovoj tvrdnji o njegovim načelima pravednosti kao o načelima teorijski (etički) višega reda. Zaključno je pokazano da u njegovoj filozofiji ne postoji proturječnost stajališta o intuiciji moralnosti.

Ključne riječi: intuicija, pravednost, nepristranost, jednakost, fundacionalizam.

»Blago gladnima i žednima pravednosti: oni će se nasititi!« (Mt 5, 6)

\footnotetext{
* Dr. sc. Marko Jakić, naslovni asistent na Odjelu za filozofiju Sveučilišta u Zadru, Obala kralja Petra Krešimira IV., br. 2, HR-23000 Zadar.
} 


\section{Uvod}

Problem intuicije u suvremenoj filozofiji općenito je vezan uz problem mogućnosti racionalnog spoznavanja osnovnih načela našeg prosuđivanja. U spoznajnom smislu vezan je uz mogućnost neposrednog ili posrednog racionalnog određivanja temeljnih iskaza za čiju istinitost ili neistinitost nije uvijek moguće pronaći formalnu proceduru odlučivanja. U ontološkom smislu vezan je uz mogućnost neposredne ili posredne spoznaje temeljnih obilježja našega uma. Ovaj općeniti filozofski problem, »po prirodi stvari« u filozofskom istraživanju, ostavio je snažan teorijski utjecaj na etiku kao filozofsku refleksiju o moralnosti.

Neposredni (direktni) intuicionizam u dijelu zapadne etičke misli (npr. G. E. Moore, W. D. Ross) utemeljen je na ideji prema kojoj se o istinitosti ili lažnosti moralnih prosudbi može odlučiti neposredno, na temelju samo-evidentna moralnog uvida. Bez obzira na međusobne razlike u mišljenjima o tome o kojim moralnim istinama intuitivno možemo odlučiti, inačicama ove vrste intuicionizma zajednička je tvrdnja o mogućnosti neposredne moralne samo-evidencije. Tako je Moore, kao zagovornik utilitarizma, ustvrdio unutarnju (intrinsic) samo-evidentnost moralnih vrijednosti, a Ross, kao kritičar utilitarizma, ustvrdio je u prvom licu (prima facie) samo-evidentnost uvida u moralnu dužnost. ${ }^{1}$

No tijekom vremena, inačice neposrednog moralnog intuicionizma pretrpjele su oštru kritiku upućenu od strane pripadnika moralnog relativizma (npr. G. Harman, D. Wong). Tako je Harman, značajan predstavnik normativnog moralnog relativizma, ustvrdio da osjećaj moralne obveze može omogućiti opravdanje pojedinačnih vjerovanja i djelovanja, ali objašnjenje ove mogućnosti postoji samo ako pojedinac nije izuzet iz kulturnog konteksta društvene grupe čija moralna stanovišta dijeli. Bez obzira na posebne želje i namjere pojedinaca, njihov osjećaj moralne obveze uvelike je određen prevladavajućim normama zajednica kojima pripadaju. ${ }^{2}$ Uslijedilo je razdoblje teorijske uspješnosti mo-

\footnotetext{
${ }^{1} »$ The conscious endeavor to avoid them all, and to apply to all the ordinary objects of ethical judgment these two questions and these only: Has it intrinsic value? and Is it a means to the best possible? - this attempt, so far as I know, is entirely new; and its results, when compared with those habitual to moral philosophers, are certainly sufficiently surprising: that to Common Sense they will not appear so strange« [George A. MOORE, Principia Ethica, 1903, assets.cambridge.org/97805214/43784/sample/9780521443784ws.pdf (30.11.2017)].

»They do stand in this relation to me, and this relation is morally significant. But they may also stand to me in the relation of promise to promiser, of creditor to debtor, of wife to husband, of child to parent, of friend to friend, of fellow countryman to fellow countryman, and the like; and each of these relations is the foundation of a prima facie duty, which is more or less incumbent on me according to the circumstances of the case « [William D. ROSS, The Right and the Good, spot.colorado.edu/ heathwoo/readings/ross.pdf (30.11.2017)].

2 »A moral observation does not seem, in the same sense, to be observational evidence for or against any moral theory, since the truth or falsity of the moral observation seems to be completely irrelevant to any reasonable explanation of why that observation was made « [Gilbert HARMAN, The Nature of Morality, u: Samuel M. CAHN i dr. (ur.), Ethics, History, Theory, and
} 
ralnog relativizma prema kojem se o istinitosti ili lažnosti moralnih prosudbi može odlučivati samo relativno, tj. samo intrinzično, u odnosu na različita povijesna razdoblja u kojima su postojale međusobno različite društvene okolnosti. Krajnja i nezaobilazna posljedica bila je tvrdnja da opravdano nije moguće bilo koje moralno stajalište izdvojiti kao etički privilegirano u odnosu na bilo koje drugo i drugačije moralno stajalište. Moralni relativizam značajno je prisutan sve do danas. Tako Wong brani tezu deskriptivnog moralnog pluralističkog relativizma, prema kojemu poimanje moralnosti osoba koje pripadaju međusobno civilizacijski različitim društvima ne može biti prosuđivano u terminima jednih ili drugih, budući da se radi o međusobno bitno nesumjerljivo različitim kulturnim »univerzumima « vrijednosti. ${ }^{3}$ Krajnja posljedica deskriptivnog relativizma je tvrdnja prema kojoj je upitno dijele li uopće pripadnici međusobno različitih kultura iste moralne izvornike, te je stoga upitno dijele li uopće u bilo čemu istovjetne čimbenike međusobno različitih moralnih perspektiva.

Moralne intuicije, dakle, protumačene uz pomoć normativnog i/ili deskriptivnog relativizma, ne mogu biti ništa više nego samo posljedice različitih društvenih okolnosti i tradicija. Time se one uvijek mogu izvesti i/ili svesti na te iste društvene okolnosti i tradicije.

\section{Kritika moralnog relativizma i moralni fundacionalizam}

Ovaj zajednički rezultat normativnog i deskriptivnog moralnog relativizma izazvao je kritiku od strane teoretičara povijesnog moralnog pluralizma. S krajnjom redukcionističkom posljedicom inačica dosljednog moralnog relativizma, tj. s tvrdnjom prema kojoj »fenomen« moralnosti kao bitno obilježje ljudskih bića nezavisno uopće ne postoji, budući da je uvijek svodiv na posebnost određene društvene okolnosti, nisu se složili teoretičari povijesnog moralnoga pluralizma (npr. J. Habermas, A. MacIntyre). Teorijske postavke povijesnog moralnoga pluralizma, zbog njihove izrazito neredukcionističke naravi, mo-

Contemporary Issues, Oxford, Oxford University Press, 2006, 627]. Također: »According to my current understanding of realistic moral relativism, it is roughly the claim that there is not a single true morality (...) morally right or wrong, good or bad, just or unjust, etc. is a relative matter-relative to one or another morality or moral frame of reference. Something can be morally right relative to one moral frame of reference and morally wrong relative to another « [Gilbert HARMAN, Moral Realism is Moral Relativism (25.06.2012), https//www.princeton. edu/ harman/Papers/Relativism.pdf (30.11.2017)].

3 »Moral ambivalence is the phenomenon of coming to understand and appreciate the other side's viewpoint to the extent that our sense of the unique rightness of our own judgments gets destabilized (...) The detached perspective from which we recognize a broader array of genuine values is also an engaged perspective from which our original moral commitments become broader and more inclusive. To recognize other's commitments or one's own as partial selections from a universe of values is, after all, to recognize that such commitments concern genuine value, if not all value« (David WONG, Natural Moralities. A Defense of Pluralistic Relativism, Oxford, Oxford University Press, 2006, 5, 236). 
guće je orijentacijski naznačiti kao teorijske postavke koje samo uvjetno moguće sadrže čimbenik koji može pripadati postavkama moralnog relativizma. Naime, činjenica postojanja pluralizma moralnih intuicija, koje su nesumnjivo postojale tijekom povijesti, ovdje doista jesu protumačene uz pomoć uvjetovanja različitim povijesnim društvenim okolnostima, ali bez negiranja postojanja njihova nereducibilna ontološkog izvornika.

Drugim riječima, pluralizam moralnih intuicija ovdje je protumačen $u$ društvenom kontekstu njihova povijesnog nastanka, ali bez redukcionističkog negiranja postojanja njihova nezavisna moralnog izvornika kao ontološke potencijalnosti koja povijesno aktualno omogućuje napredak k stupnjevito univerzalnijim sintezama moralnog standarda. Kao temeljni oslonac ovim postavkama, teoretičarima povijesnog moralnog pluralizma poglavito je poslužilo Hegelovo »konkretno-univerzalno« - u Hegelovoj filozofiji povijesti dijalektički spoznajno djelatno tijekom povijesnog razvoja pojma moralnosti. Hegelova filozofija povijesti nije dopuštala zanemarivanje društveno antitetički uvjetovana univerzalno sintetičkog teorijskog doprinosa konkretnih pojedinaca pri povijesnom razvoju pojma moralnosti, ali isto tako nije dopuštala ni redukciju univerzalne teorijske sinteze o moralnosti na samo konkretne povijesne uvjete. I to na bilo kojem stupnju antitetičkog povijesnog razvoja pojma moralnosti. Hegelovo »konkretno-univerzalno « nedvojbeno je sadržavalo mogućnost objašnjenja međusobno različitih intuicija o moralnosti bez redukcionističkog postupka koji bi negirao postojanje nezavisna ontološkog izvornika moralnosti. Od Hegelova »razvoja pojma moralnosti« inače teško da bi teorijski spoznajno neproturječno ostalo gotovo išta. Naime, istinitost moralne intuicije iz jednog konkretnog povijesnog razdoblja bila bi antitetički u cjelini negirana od strane istinitosti moralne intuicije iz drugog konkretnog povijesnog razdoblja. Time bi se svaka moralna intuicija, antitetički povijesno relativizirana, pokazivala proturječno ujedno i istinitom i neistinitom. No sintetički napredak u spoznaji istinitosti o pojmu moralnosti nije u Hegelovoj filozofiji dopuštao ovu vrstu povijesnog relativizma. Stoga je spoznaja istinitosti o pojmu moralnosti mogla u hegelovskoj filozofiji antitetičko-sintetički stupnjevito pluralistički napredovati, bez njezina svođenja isključivo samo na povijesnu antitetičku relativizaciju.

Oslonivši se na Hegelovu dijalektiku, »očistivši« je od »supstancijalnih« dijelova Hegelove filozofije, teorijski općenito radi uspostavljanja svoje teorije komunikacijskog djelovanja, te posebno onda i radi uspostavljanja svoje »diskurzivne etike «, Habermas je ustvrdio da je u pluralističkim i multikulturalnim uvjetima suvremenih demokratskih društava, a uz pomoć društveno realne demokratske rasprave, moguće postići sintetičko jedinstvo međusobno različitih moralnih intuicija. Diskurzivna etika ovdje je uspostavljena kao idealna rekonstrukcija rezultata ovog demokratskog diskursa. Time se je objašnjenje pluralizma moralnih intuicija, sasvim dosljedno hegelovski neredukcionistički, 
u Habermasovoj filozofiji približilo mogućnosti sintetički jedinstvenog tumačenja. ${ }^{4}$

S druge strane, MacIntyre je doveo u pitanje relativističku tezu o nesumjerljivosti različitih kulturnih tradicija. Nije negirao postojanje situacija u kojima unaprijed (a priori) nije moguće pronaći racionalan način razrješenja neslaganja između međusobno moralno suprotstavljenim tradicijama. No objašnjenje zajedničkih značajki uz pomoć kojih se dvije međusobno suprotstavljene kulturne tradicije uopće mogu međusobno prepoznati, objašnjenje mogućnosti međusobnog prepoznavanja usporednih sličnosti u njihovim praktičkim postupcima, te objašnjenje nekih zajedničkih značajki u poimanju ljudskog dobra, nije unaprijed bilo moguće bez oživljenja kantovskog transcendentalna projekta. ${ }^{5}$ Traganje za zajedničkim moralnim standardima nametnulo se je iz općenitog filozofskog traganja za relevantnim razmatranjima i uzrokovanjima. Naime, ustvrdio je MacIntyre, kada odričemo istinitost nečijih moralnih vjerovanja, mi prosuđujemo protiv primjerenosti (adekvatnosti) razloga za njegova vjerovanja, kao i protiv primjerenosti uzroka koje netko navodi za svoja vjerovanja.

Neke najbolje primjere potrage za ovim zajedničkim moralnim standardima moguće je pronaći u međusobnim neslaganjima kod nekih srednjovjekovnih židovskih, islamskih i kršćanskih filozofa. ${ }^{6}$ MacIntyre se, bez obzira što

${ }^{4}$ »Kant's categorical imperative already goes beyond the egocentric character of the Golden Rule: 'Do not do unto others what you would not have them do unto you'. Whereas this rule calls for a universalization test from the viewpoint of a given individual, the categorical imperative requires that all those possibly affected be able to will a just maxim as a general rule. But as long as we apply this more exacting test in a monological fashion, it still remains individually isolated perspectives from which each of us considers privately what all could will (...) But this can no longer be assumed under conditions of social and ideological pluralism. If we wish to preserve the intuition underlying the Kantian universalization principle, we can respond to this fact of pluralism in different ways (...) I propose that philosophy limit itself to the clarification of the moral point of view and the procedure of democratic legitimation, to the analysis of the conditions of rational discourses and negotiations. In this more modest role, philosophy need not proceed in a constructive, but only in a reconstructive fashion " [Jürgen HABERMAS, Reconciliation Through the Public use of Reason. Remarks on John Rawls's Political Liberalism, The Journal of Philosophy, 92 (1995) 3, 131].

5 »If two moral traditions are able to recognize each other as advancing rival contentions on issues of importance, then necessarily they must share some common features. And since some kind of relationship to practices, some particular conception of human goods, some characteristics which arise from the very nature of a tradition will be features of both, this is unsurprising. (...) for relativistic thesis would emerge (...) For my position entails that there are no successful $a$ priori arguments which will guarantee in advance that such a situation could not occur. Indeed, nothing could provide us with such a guarantee which did not involve the successful resuscitation of the Kantian transcendental project (Alasdair MacINTYRE, After Virtue, London, Duckworth, 1985, 276-277).

6 "When we deny the truth of someone else's moral beliefs and give our grounds for so doing, we make or imply judgments about the inadequacy of their reasons for belief and about the causes of their belief. And we presuppose a difference between them and us in both respects. In so doing we provide matter for a shared philosophical inquiry about the relevant types of reason and cause. It is a mark of rational disagreement on matters of serious moral import that we 
inače žestoko kritizira Kantov moralni projekt, kada osporava relativističku tezu o nesumjerljivosti međusobno različitih kulturnih (te stoga i moralnih) tradicija poziva upravo na kantovski transcendentalni projekt. MacIntyreova kritika načina na koji je Kant izvodio svoj moralni projekt nije morala povući i MacIntyreovo osporavanje same Kantove postavke o postojanju ontološkog izvornika moralnosti. Moralne intuicije, dakle, protumačene uz pomoć teorijskih postavki povijesnog moralnoga pluralizma, ni u kom slučaju nisu mogle biti reducirane isključivo samo na društvene okolnosti. Upravo suprotno, ove teorijske postavke pretpostavile su postojanje nereducibilna ontološkog izvornika međusobno različito povijesno uvjetovanih moralnih intuicija.

No ovaj izvornik svejedno je kod teoretičara neredukcionističkog povijesnog moralnog pluralizma ostao neimenovan. Mislim da su barem dva glavna razloga za ovo neimenovanje. Prvi razlog treba potražiti u dosljednom slijeđenju Hegelove filozofije. Sâmo imenovanje izaziva naime sljedeći teorijski oprez: Postoji opasnost od gubitka slijeda antitetičko-sintetičke dijalektičke strukture Hegelova »konkretno-univerzalnog«. Odnosno, postoji opasnost od gubitka slijeda načina na koji je Hegel kritizirao Kantov kategorički imperativ kao sadržajno prazan, budući da njegova univerzalnost neopravdano zanemaruje konkretnost, te da se stoga (protu)činjenično ne odnosi ni na jedno konkretno povijesno razdoblje. Drugi razlog treba potražiti u teorijski slaboj točki neposrednog moralnoga intuicionizma. Ova slaba točka pokazala se u poteškoći uvjerljivog objašnjenja činjenice da su u različitim povijesnim i društvenim okolnostima konkretne neposredne intuicije o moralnoj »samo-evidentnosti « i moralnoj »dužnosti« bile međusobno proturječne, te su posljedično stoga $\mathrm{i}$ teorijski nezaobilazno bile etički međusobno nespojive.

No problem racionalne spoznaje osnovnih načela našeg prosuđivanja svejedno je ostao općenito važan filozofski problem. Problem koji je jednim svojim dijelom vezan uz određenje statusa moralnih intuicija u filozofskoj refleksiji o moralnosti.

U drugom dijelu zapadne etičke misli (npr. I. Kant, J. Rawls) problem statusa moralnih intuicija posebno je istaknuto problematiziran u teorijskim okvirima posrednog (indirektnog) intuicionizma. Naime, za uvjerljivo fundacionalističko objašnjenje povijesno nedvojbeno utvrđenih činjenica da su u različitim povijesnim razdobljima postojale društveno uvjetovane i međusobno moralno nespojive intuicije o moralnosti, trebao je teorijski napor veće objašnjujuće moći od onog kojeg je mogao ponuditi neposredni intuicionizam. Prigovor moralnom relativizmu da je izvođenjem moralnosti iz povijesnih okolnosti, tj. da je svođenjem moralnosti na društvenost, porekao postojanje »fenomena«

who so disagree should be prepared to engage in this inquiry and to recognize its standards as binding on us unqualified. This recognition commits us to a denial of moral relativism « [Alasdair MacINTYRE, Moral Pluralism Without Moral Relativism, u: Jaakko HINTIKKA i dr. (ur.) The Proceedings of the Twentieth World Congress of Philosophy, 1 (1999) 1-8, 1]. 
moralnosti kao bitnog obilježja ljudskoga bića, makoliko općenito filozofski bio snažan prigovor, zbog svoje negativne naravi nije ujedno mogao biti i teorijski zadovoljavajuće dovoljan prigovor. Negiranje nepostojanja »fenomena« moralnosti općenito nikako ujedno nije moglo biti i teorijski zadovoljavajuće ne-negativno (pozitivno, ali ne i pozitivističko) određenje njegova spoznajnog i ontološkog statusa. Stoga teret teorijskog imenovanja i dokazivanja postojanja neproturječno neovisna ontološkog izvornika »fenomena" moralnosti svakako nije pripadao ideji moralnog relativizma, nego je pripadao ideji moralnog fundacionalizma. Ideji koja je vodila tvrdnji o postojanju neovisnog moralnog fundamenta kao izvornika naših moralnih intuicija. Tek je posredno teorijsko dokazivanje u prilog tezi o postojanju »ni na što drugo osim na sama sebe« svodiva ontološkog izvornika naših moralnih intuicija moglo ponuditi ne-relativističko, ne-redukcionističko, te ujedno i fundacionalističko objašnjenje društveno uvjetovanih povijesnih razlika u intuicijama o moralnosti. Pri takvom dokazivanju činjenica postojanja društvenog utjecaja na intuicije o moralnosti u međusobno različitim povijesnim odsječcima, te u međusobno različitim kulturnim tradicijama, nikako nije smjela biti teorijski zanemarivana.

Kant je za svoj kategorički imperativ, uspostavivši ga kao moralni zakon, ustvrdio da je on moralno sredstvo uz pomoć kojega je u aposteriornoj realnosti moguće razdvojiti moralno dobro od zla. Ovo imperativno moralno razdvajanje trebalo je moći konkretno djelovati u bilo kojoj društvenoj zadanosti, no nikako nije smjelo biti i izvodivo iz te iste bilo koje društvene zadanosti. Metodološki paradoks uspostave moralnog zakona, izazvan nezaobilaznim uvjetom da unaprijed ne smijemo odrediti što je to moralnost, značio je da ga je bilo moguće uspostaviti samo posrednim teorijskim dokazom kao činjenicu (factum) uma i to isključivo samo na apriornom području transcendentalna istraživanja. Ovaj metodološki paradoks Kant je razriješio posredstvom svojih kategorija mogućnosti i uzročnosti. Pri ovom razrješenju kategorija mogućnosti bila je nužna zbog samog uspostavljanja mogućnosti moralnog izbora. No nije mogla biti i dovoljna, zbog moguće proizvoljnosti pri tom izboru. Kategorija uzročnosti osiguravala je i dovoljnost pri ovom razrješenju. Samo pod kategorijom uzročnosti volja je na transcendentalnom području etičkoga istraživanja mogla sebe prepoznati kao dobru volju. Odnosno, volja je mogla spoznati »bezuvjetno moralno dobro « kao činjenicu uma. Prema Kantovoj filozofiji, ova fundamentalna moralna činjenica je ničim izvan same sebe uvjetovan, te je stoga dakle izvjesno ontološki neovisan izvornik naših moralnih intuicija. ${ }^{7}$

\footnotetext{
»Kako dakle pojmovi dobra i zla kao posljedice određenja volje a priori pretpostavljaju i neki čisti praktički princip, dakle kauzalitet čistog uma, to se oni prvobitno ne odnose (možda kao određenje sintetičkog jedinstva raznolikosti danih zorova u svijesti) na objekte kao čisti razumski pojmovi ili kategorije teorijski upotrijebljenog uma, nego ih, štoviše, pretpostavljaju kao dane. Naprotiv su oni svi zajedno modusi jedne jedine kategorije, naime kategorije kauzaliteta, ukoliko se njezin odredbeni razlog sastoji u umskoj predodžbi nekog zakona što ga kao zakon slobode um sam sebi daje, pokazujući se na taj način a priori kao praktički. Kako,
} 
Na ovaj Kantov rezultat teorijski je nastavio Rawls pretpostavivši inteligibilan »osjećaj« za pravednost. ${ }^{8}$ Pravednost je naime zasigurno dio Kantova »ničim uvjetovana moralnoga dobra«. Rawls je s pravom ustvrdio da za postavke o moralnosti iskazane u njegovoj filozofiji uvijek postoji kantovska interpretacija. No ima li ovo, utemeljeno posredstvom kantovski orijentirana teorijskog dokaza, imenovanje izvornika moralne intuicije doista uvjerljivo veću objašnjujuću moć od one koju je ponudio neposredni intuicionizam? Odnosno: Ima li Rawlsova filozofija dovoljno objašnjujuće moći za neproturječno fundacionalističko objašnjenje činjenice da su u različitim povijesnim razdobljima postojale međusobno nespojive intuicije o moralnosti?

Rawls je u Teoriji pravednosti, u svom misaonom pokusu, a iza vela neznanja, imenovao osjećaj za pravednost kao ontološki moralni temelj iz kojeg su slijedila dva načela pravednosti. Dva načela pravednosti zatim su mu putem ove »arhimedovske točke« poslužila kao teorijsko uporište za njegovu konstrukciju društvenog ugovora. ${ }^{9}$ Stoga bi sam osjećaj za pravednost kao intuitivan moralni izvornik načela pravednosti doista morao imati dovoljnu teorijsku objašnjujuću moć za neproturječno objašnjenje činjenice da su tijekom povijesti postojale različite i etički međusobno nespojive intuicije u poimanju pravednosti.

međutim, radnje s jedne strane doduše spadaju pod zakon, koji nije prirodni zakon, nego zakon slobode, prema tome pripadaju odnošenju inteligibilnih bića, ali s druge strane kao zbivanja u osjetilnom svijetu ipak pripadaju i pojavama, to će određenja praktičkog uma moći da postoje samo u pogledu potonjih, dakle primjereno doduše kategorijama razuma, ali ne u pogledu neke njegove teorijske upotrebe, kako bi raznolikost (osjetilnog) zrenja sveo pod svijest a priori, nego samo da raznolikost želja podvrgne jedinstvu svijesti praktičkog uma, koji zapovijeda u moralnom zakonu, ili jedinstvu čiste volje a priori« (Immanuel KANT, Kritika praktičkog uma, prev. V. D. Sonnenfeld, Zagreb, Naprijed, 1990, 103-104).

»Pravo štovanje moralnog zakona jest dakle osjećaj koji se stvara intelektualnim razlogom [ein Gefühl, welches durch einen intellektuellen Grund gewirkt wird], a taj je osjećaj ono jedino što spoznajemo potpuno a priori i čiju nužnost mi možemo uvidjeti. U pređašnjem smo poglavlju vidjeli da se sve što se prije moralnog zakona pokazuje kao objekt volje isključuje iz odredbenih razloga volje samim tim zakonom kao najvišim uvjetom praktičkog uma pod imenom bezuvjetno-dobroga, i da sama praktička forma, koja se sastoji u sposobnosti maksima za opće zakonodavstvo, određuje najprije ono što je po sebi i apsolutno dobro i da osniva maksimu čiste volje, koja je jedina u svakom pogledu dobra (isto, 114).

${ }^{8}$ Inteligibilnost »osjećaja« za pravednost nesumnjivo sigurno pokazuje da je u Rawlsovoj filozofiji riječ o racionalno izrecivom smislu za pravednost, a ne o osjećaju u mogućem značenju emocije za pravednost. Rawls u Teoriji pravednosti dosljedno rabi pojam »sense of justice«. Pojam »osjećaj« za pravednost, a ne daleko primjereniji pojam »smisao « za pravednost, ovdje sam zadržao zbog prijevoda, do sada oskudnih, dijelova Rawlsove filozofije na hrvatski jezik, a u kojima je pojam »sense of justice« preveden kao »osjećaj za pravednost«.

9 »Pretpostavljajući određene opće želje kao što je želja za primarnim društvenim dobrima i uzimajući kao temelj suglasnost koja bi bila postignuta u odgovarajuće definiranoj početnoj okolnosti, možemo postići nužnu neovisnost o postojećim okolnostima. Izvorni položaj je tako određen da je jednoglasnost moguća; rasuđivanja bilo koje osobe su tipična za sve. Štoviše, isto će vrijediti za promišljene sudove građana pripadajućih dobro uređenim društvima učinkovito reguliranih načelima pravednosti. Bilo tko od njih ima sličan osjećaj za pravednost i u ovom smislu je dobro uređeno društvo homogeno. Politički argument se poziva na ovaj moralni konsenzus «, prev. a., (John RAWLS, A Theory of Justice, Massachusetts, The Belknap Press of Harvard University Press, 2. prep. izd., 1999, 232). 
Radi pobližeg određenja objašnjujuće moći ovog izvornika promotrimo ukratko na rolsovski način realnu povijesnu činjenicu koja je u barem jednoj državi zapadne demokracije ustrojstveno društveno konkretno postojala do polovice devetnaestog stoljeća. ${ }^{10}$ Naznačimo neke značajke društvene okolnosti postojanja robovlasništva u ovom odsječku povijesti s obzirom na intuicije pravednosti. Intuicije o pravednosti postupaka tada su se zasigurno uvelike međusobno razlikovale kod robova i kod robovlasnika. Robovlasnici su definirali robove kao manje sposobna bića koja intelektualno samostalno nisu u stanju brinuti se o samima sebi u kulturno razvijenom i civilizacijski složenom društvenom ustrojstvu u kojem su se našli. Samo-evidentna je stoga bila moralna dužnost njihovih gospodara da se umjesto njih pobrinu za njihove potrebe. Osiguranje osnovnih potreba za njihovo preživljavanje se u očima njihovih gospodara pričinjavalo pravednom nadoknadom za njihov ropski rad. Teško da su se i robovi dragovoljno slagali s ovom robovlasničkom definicijom o njima, teško da su se slagali s ovakvim pretpostavkama o njihovim potrebama, te da su se slagali s ovakvom robovlasničkom intuicijom o pravednosti postupka prema njima.

No istovremeno, za slučajeve kršenja pravednosti postupka prema bilo kojem robovlasniku od strane bilo kojeg drugog robovlasnika postojao je demokratski javno ustrojen i razvijen pravni sustav. Demokratskom raspravom usuglašen sustav u skladu s intuicijama o pravednosti svih građana, pa onda i građana robovlasnika kao međusobno ravnopravnih građana. Građanske intuicije o pravednosti tada zasigurno nisu međusobno bile toliko različite da bi spriječile demokratsku suglasnost pri donošenju propisa koji su jamčili pravednost postupaka pri razrješenju međusobnih građanskih pravnih sporova. Činjenica da sinergija tih istih intuicija o pravednosti nije djelovala i za slučaj robova, od kojih »naravno" ni jedan nije imao građanski status, zasigurno ovdje nije bila uzrokovana razlikom među građanskim intuicijama o pravednosti postupaka prema njima, nego je uzrokovana društveno javno usvojenom definicijom o njima kao manje sposobnim bićima koja su samo nalik ljudskim bićima. S druge strane, za slučajeve prekršaja postupaka pravednosti prema bilo kojem robu od strane bilo kojeg drugog roba, bilo koji rob mogao se je potužiti svom gospodaru. Samo-evidentna moralna dužnost bilo kojeg takvog gospodara bila je da ispravi takvu nepravednost.

Činjenica da je građanska robovlasnička intuicija o pravednosti u sličnim slučajevima mogla djelovati i za slučaj robova, sada više nije mogla neproturječno potkrijepiti tezu o nepremostivo značajnim međusobnim razlikama $u$ intuicijama o pravednosti kod gospodara i kod robova. Upravo suprotno, na intuiciju pravednosti u ovakvim slučajevima pozivali su se, »naravno « ne u bilo kojoj međusobnoj komunikaciji koja bi mogla sadržavati bilo koji element međusobne jednakosti, i robovi i gospodari. Inače ni jedan rob ne bi bio u stanju

\footnotetext{
${ }^{10}$ Primjer je u cjelini moj i nije ni na koji način preuzet iz literature ili tuđeg priopćenja.
} 
ni zamijetiti da je pretrpio nepravednost koja mu je nanesena od strane nekog drugog roba, niti bi to na gospodaru razumljiv način, tražeći njegovu zaštitu, uopće i mogao priopćiti. Svejedno je poziv na pravednost bio komunikacijski razumljiv i robovlasnicima i robovima. I to bez obzira na to što su ovi drugi tobože bili »manje sposobna bića«. Postojale su tada, dakle, društveno ekstremno uvjetovane razlike u poimanjima načina primjene poziva na pravednost, ali ne i činjenično uvjerljivo neproturječno dokazive međusobno nespojive intuicije o pravednosti. Razumno je pretpostaviti da ono što vrijedi za društveno ekstremno uvjetovane okolnosti teško da ne vrijedi i za manje ekstremno uvjetovane društvene okolnosti. Sve do danas.

Ovaj primjer pokazuje da kantovsko posredno i autonomno imenovanje izvornika moralnih intuicija doista ima veću teorijsku objašnjujuću moć od neposredne heteronomije imenovanjâ koju je jedino i mogao ponuditi neposredni intuicionizam. Mislim da primjer pokazuje i da Rawlsovo fundacionalističko imenovanje moralnog izvornika doista ima dovoljno teorijske objašnjujuće moći za neproturječno objašnjenje činjenice da su u različitim povijesnim razdobljima postojale međusobno različito društveno uvjetovane, te stoga na prvi pogled i međusobno nespojive intuicije o pravednosti. Ovdje treba istaknuti da rolsovsko objašnjenje izvjesno uključuje kantovsku interpretaciju koja neotklonjivo zahtijeva ne-svođenje moralnosti na društvenost, te nezaobilazno onda zahtijeva i njezino ne-izvođenje iz bilo koje vrste povijesne okolnosti. Primjer također ističe itekako važnu ulogu ustrojstvenih elementa društava pri uzročnom objašnjenju pluralizma intuicija o pravednim postupcima. No bez redukcionističkog relativizma.

$\mathrm{S}$ ovim načinom objašnjenja navedenog primjera i s prethodno navedenim zahtjevima pri ovom objašnjenju teško da bi se dosljedno hegelovski mogli ne složiti zagovornici teorije koja s pravom pokušava objasniti činjenicu postojanja pluralizma moralnih doktrina u suvremenim demokratskim društvima. I to bez obzira što u nekim njezinim inačicama postoji oprez u odnosu na neproturječnu mogućnost imenovanja samog moralnog izvornika doktrinarno uvjetovanih i međusobno različitih intuicija o pravednosti. Teško je naime, nakon rolsovski naknadnog određenja dvaju načela pravednosti, a slijedom kantovski naknadnog transcendentalnog razrješenja metodološkog paradoksa pri određenju sadržaja moralnosti, s velikom uvjerljivošću i nadalje tvrditi da pravednost kao nepristranost nije ništa više nego samo jedna od mogućih definicija pravednosti. Definicija koja doduše jest posredno dovela do dvaju načela pravednosti, ali je u konačnici ipak teorijski pretpostavljena unaprijed. Poteškoća je vidljiva ako se pokuša sa sljedećim i jedino mogućim drugačijim osporavanjima, ili drukčijim određenjima, obilježjâ pravednosti pri definiciji pojma pravednosti: Pravednost koja nije nepristranost ili pravednost koja je ujedno i nepravednost ili pravednost koja kao pojam uopće samostalno smisleno ne može ni postojati? Prva definicija je besmislena, a ostale dvije vode u redukcionistički relativizam. 
No redukcionistički relativizam je teorijski daleko od dosljedna hegelovskog tumačenja povijesnim civilizacijskim dostignućima omogućena spoznajnog razvoja o pojmu moralnosti. Stoga je onda ujedno teorijski nužno daleko i od dosljedna hegelovskog tumačenja razvoja pojma pravednosti.

$\mathrm{S}$ druge strane, teško je odreći značajnu teorijsku podudarnost dosljedna hegelovskog tumačenja razvoja pojma pravednosti s Rawlsovim stajalištima. Rawls naime uz pomoć svog misaonog pokusa u Teoriji pravednosti nije uspostavio samo teorijski apstraktno domišljenu ontološku konstantnost obilježjâ nepristranosti i jednakosti u pojmu pravednosti, nego je uz pomoć načela pravednosti utkanih u pozadinske institucije dobro uređenih društava pretpostavio i mogućnost društvenog razvoja tih istih obilježja pojma pravednosti. Odnosno, pretpostavio je razvojnu prisutnost osjećaja za pravednost kod konkretnih osoba pripadnika dobro uređenih društava. Kao civilizacijsku i kulturološku stečevinu koja uz racionalnost čini društvenu razboritost. Pretpostavio je mogućnost razvoja društvene razboritosti koja omogućuje društveni javni um kao jamac stabilnosti društava s demokratskim političkim ustrojstvom, razvoj društava koja su daleko od utopijskog savršenstva.

No, ustvrdio je Rawls, intuicionističko poimanje pravednosti samo je polovica poimanja. Ako ne možemo objasniti da vrijednosti mogu biti određene uz pomoć razumnih etičkih mjerila, onda smisao racionalne rasprave o moralnosti dolazi do svog kraja. Trebamo uraditi sve što možemo da bismo uobličili prioritetna načela, bez obzira što ovisnost o intuiciji ne može potpuno biti odstranjena. ${ }^{11}$

No sada moramo upitati: Je li Rawls, zbog svoje kritike intuicionizma, a uz istovremeno iskazanu ovisnost o intuiciji, upao u teorijski neprihvatljivu proturječnost stajališta?

\footnotetext{
${ }^{11} »$ As I have already remarked, there is nothing necessarily irrational in the appeal to intuition to settle questions of priority. We must recognize the possibility that there is no way to get beyond a plurality of principles. No doubt any conception of justice will have to rely on intuition to some degree. Nevertheless, we should do what we can to reduce the direct appeal to our considered judgments. For if men balance final principles differently, as presumably they often do, then their conceptions of justice are different. The assignment of weights is an essential and not a minor part of a conception of justice. If we cannot explain how these weights are to be determined by reasonable ethical criteria, the means of rational discussion have come to an end. An intuitionistic conception of justice is, one might say, but half of conception. We should do what we can to formulate explicit principles for the priority problem, even though the dependence on intuition cannot be eliminated entirely. (...) Most traditional doctrines hold that to some degree at least human nature is such that we acquire a desire to act justly when we have lived under and benefited from just institutions. To the extent that this is true, a conception of justice is psychologically suited to human inclinations (Rawls, A Theory of Justice..., 399).
} 


\section{Intuicija pravednosti i prioritetnost načela}

Da ovisnost o intuiciji u Rawlsovoj teoriji ne može u cijelosti biti odstranjena jasno je iz njegova poziva na intuiciju pravednosti. I to ovisnost o neposrednom pozivu na intuiciju! Rawls se tako u Društvu narodâ neposredno obraća intuiciji građana obdarenih moralnim moćima pravednosti i moralnog dobra. ${ }^{12} \mathrm{No}$ što to intuitivno neposredno ovdje građani trebaju procijeniti? Odgovor na ovo pitanje je raspravljen i jednoznačno određen uz pomoć postavljenih teorijskih ciljeva u Političkom liberalizmu..$^{13}$ Rawls se obraća građanima da racionalno procijene moralnu opravdanost njegove konstrukcije društvenog ugovora. Odnosno, Rawls ostavlja čitateljima da, u skladu s svojim racionalnim i moralnim intuitivnim moćima, procijene teorijsku razložnost i praktičnu razboritost njegove cjelokupne teorije. Prvi Rawlsov uvjet pri tom je da građani pristaju na demokratsko društveno ustrojstvo. I to bez obzira na to koju od religijskih i/ili filozofskih doktrina ti građani moguće zastupaju. Rawlsova pretpostavka je da bi time moglo doći do racionalnog i moralnog slaganja oko temeljnih društvenih načela. Drugi Rawlsov uvjet je da građani pristaju na to da sloboda svake osobe prestaje tamo gdje započinje sloboda neke druge osobe. Rawlsova pretpostavka je da bi time bila umanjena opasnost od realnog ostvarenja nekog oblika samovolje. I to bez obzira na to jesu li čimbenici koji možda vode u neki oblik osobne i/ili društvene samovolje doktrinarno uvjetovani religijskim i/ili filozofskim razlozima.

S obzirom na ovako zahtijevane uvjete, temeljna načela njegove konstrukcije društvenog ugovora morala su biti postavljena tako da su uvelike razumno prihvatljiva u suvremenim uvjetima političkog doktrinarnog pluralizma. Morala su dakle u visokom stupnju teorijske razložnosti biti dovoljno potkrijepljena tako da su intuitivno mogla biti prihvatljiva kao društveno razborit jamac očuvanja samopoštovanja osoba, te time jamac očuvanja stabilnosti društva. ${ }^{14}$

\footnotetext{
$12 »$ Iznoseći razloge pred sve građane mi ne shvaćamo osobe kao društveno vezane ili na drugi način ukorijenjene, to jest tako kao da pripadaju ovoj ili onoj društvenoj klasi ili imovinskoj ili prihodovnoj skupini ili da imaju ovu ili onu obuhvatnu doktrinu. A ne pozivamo se ni na interese svake osobe ili svake skupine, premda na nekom stupnju trebamo te interese uzeti u obzir. Naprotiv, mi shvaćamo osobe kao razložne i racionalne, kao slobodne i jednake građane $\mathrm{s}$ dvjema moralnim moćima [sposobnosti za koncepciju pravednosti i sposobnosti za koncepciju dobra], te koje u svakom danom trenutku imaju određenu koncepciju dobra koja se može tijekom vremena mijenjati« (John RAWLS, Društvo narodâ i preispitivanje ideje javnog uma, prev. S. Barić, M. Matulović, Zagreb, KruZak, 2004, 194-195).

${ }_{13}$ »Teorija i $P L$ pokušavaju skicirati koje su to razložnije koncepcije pravednosti za demokratski režim te prikazati kandidata za najrazložniju koncepciju. One razmatraju način na koji trebaju biti shvaćeni građani kako bi konstruirali (PL III) te razložnije koncepcije te što njihova moralna psihologija treba biti kako bi poduprla pravedno političko društvo tijekom vremena« (John RAWLS, Politički liberalizam, prev. F. Grgić, Zagreb, KruZak, 2000, LII).

${ }^{14}$ Rawlsove pojmove »reasonable« $\mathrm{i} »$ reasonableness « rabim u smislu »razborito« $\mathrm{i}$ »razboritost « kada je riječ o društvenim odlukama od kojih su neke i moralne odluke. Npr. »društvena razboritost «. Iste pojmove rabim u smislu »razložno« i »razložnost« kada se radi o razlozima koji
} 
Ove društvene vrijednosti, ustvrdio je Rawls, mogu biti procijenjene uz pomoć razumnih etičkih mjerila. Autonomnost dvama načelima pravednosti omogućavala je konstantna prisutnost obilježjâ nepristranosti i jednakosti osjećaja za pravednost kao njihov moralni intuitivni izvornik. No Rawls ih je morao i etički dokazati kao načela teorijski i praktički višega reda u odnosu na »konkurentska« načela. Odnosno, morao je dokazati teorijsku i praktičku nadređenost svojih načela pravednosti u odnosu na, kako ih je Rawls nazvao, »zdravorazumska« načela.

Drugim riječima, Rawls je morao dokazati da je javna društvena uporaba njegovih načela pravednosti uporabno nadmoćna u odnosu na javnu društvenu uporabu međusobno različitih zdravorazumskih načela. Superiornost svojih načela mogao je dokazati putem autonomne konstantnosti njihove praktičke uporabe zajamčene obilježjima nepristranosti i jednakosti njihova ontološkog izvornika. Za razliku od praktički heteronomne uporabe međusobno različitih intuicija o zdravorazumskim načelima. Pretpostavljenu praktičnu uporabnu heteronomnost zdravorazumskih načela svakako je morao prethodno i dokazati. Za ovaj dokaz trebali su mu argumenti izlučeni iz dovoljno velikog dijela povijesti. Pri ovom argumentiranju nije mu trebalo negirati tvrdnje neposrednog intuicionizma (G. E. Moore, W. D. Ross) o postojanju razumno prihvatljivih moralnih načela. Ali prihvatljivih ne samo radi njihove jednostavne intuitivne "samo-evidentnosti«, nego prihvatljivih radi njihove teorijske utemeljenosti i praktične opravdanosti. No u odnosu na intuicije zdravorazumskih načela, uklopljene u sustave oblikâ društvenih organizacija koje su u nekom dijelu povijesti pokušane biti dosljedno društveno realizirane, izlučivanje dokaza o njihovoj heteronomnoj uporabi bilo je svakako složeno. Rawls je nastojao da njegova kritika uporabe ovih međusobno različitih i u međusobno različite društvene doktrine uklopljenih intuicija o prihvatljivim načelima bude dovoljno reprezentativna. Za primjere zdravorazumskih načela promotrio je Marxovo načelo: »Od svakoga prema sposobnostima, svakome prema potrebama «, te Millovo načelo: »Svakome prema trudu i svakome prema doprinosu«.

Doktrinarno uklopljeno u društveno realiziranu i unaprijed planiranu proizvodnju, sa zahtjevom za ostvarenjem besklasnoga društva, Marxovo načelo je tijekom vremena pokazalo obilježja heteronomičnosti uporabe. Naime, proizvodnja je i mogla biti planirana unaprijed, budući da su prethodno potrebe bile planirane unaprijed. Procjene potreba unaprijed često su izazivale višak jednih i manjak drugih proizvoda. Potrebe su stoga bile ponovno procjenjivane

potkrjepljuju neku teoriju. Npr. »teorijska razložnost«. Terminološku razliku rabim stoga što teorijski i/ili praktički razlozi koji su uobličili neku teoriju ne moraju ujedno biti i dostatni razlozi za njezinu društveno razboritu uporabu. Smisao termina »razboritost« i smisao termina »razložnost« nikako se time međusobno ne isključuju. Nema naime te društvene razboritosti koja ne bi uključivala teorijsku racionalnu razložnost kao svoj nužan dio. Ako se imaju u vidu ove mogućnosti koje nudi hrvatski jezik, onda je ove Rawlsove pojmove moguće dosljedno prevesti bilo samo jednim, ili bilo samo drugim terminom. 
i to bez obzira na pojedinačna proizvodna zalaganja u skladu s sposobnostima. Heteronomičnost procjena potreba i zanemarivanje pojedinačnih zalaganja posljedično su tijekom vremena sve više negativno utjecale na ukupna proizvodna zalaganja. U konačnici se heteronomičnost uporabe Marxova načela pokazala kao jedan od čimbenika koji su dovodili do općeg pada proizvodnje u društvima planske ekonomije.

Doktrinarno uklopljeno u društveno realiziranu slobodnu poduzetničku tržišnu ekonomiju, sa zahtjevom za ostvarenjem što većeg ukupnog zbroja sreće pojedinaca, Millovo načelo je tijekom vremena također pokazalo obilježjâ heteronomičnosti uporabe. Naime, promjenom tržišnih trendova neki proizvodi su postali manje traženi i to bez obzira na pojedinačan trud uložen u njihovu proizvodnju. U slučajevima značajnih smanjenja potražnje takvih proizvoda na unutarnjem i na izvoznom tržištu, dolazilo je do značajnih otpuštanja proizvodnih djelatnika. Budući da je tržišni rizik proizvodnje obrnuto proporcionalan sa srećom pojedinaca, sada je nastajalo smanjenje minimalne dohodovne mjere koja je trebala odrediti ukupan zbroj sreće pojedinaca. I to bez obzira na uložen pojedinačan trud. Heteronomičnost uporabe Millova načela zatim je posljedično utjecala na povećanje opasnosti od društvenih kriza čiji su izraziti simptomi ekonomske krize. Ovi simptomi u utilitaristički (neoliberalistički) utemeljenim društvima tržišne ekonomije prepoznatljivi su sve do danas.

Rawlsova kritika zdravorazumskih načela nikako nije išla za tim da ih prikaže kao etički neprihvatljiva načela, nego je nastojala pokazati negativne društvene posljedice njihove heteronomične uporabe. Za razliku od sličnih zdravorazumski prihvatljivih načela, ustvrdio je Rawls, heteronomična uporaba njegovih načela pravednosti nije smisleno uopće moguća. Nema naime takve intuicije pravednosti koja ne bi vremenski nepromjenjivo zahtijevala nepristranost i jednakost. I to uporabno konstantno u međusobno različitim oblicima povijesno ostvarenih društvenih organizacija.

Ovim je ukratko naznačen dio Rawlsove činjenične argumentacije u pri$\log$ tvrdnji o prioritetnosti načelâ pravednosti. Ostalo je ukratko naznačiti i Rawlsovu teorijsku argumentaciju u prilog tvrdnji o prioritetnosti načelâ pravednosti, iskazanu uz pomoć njihova »leksičkog poretka«. Rawlsovo prvo načelo pravednosti glasi:

"Svaka osoba mora imati jednako pravo na najširi cjelokupan sustav jednakih temeljnih sloboda, usporedno sa sličnim sustavom sloboda za sve. $\ll^{15}$

Rawlsovo drugo načelo pravednosti glasi:

»Društvene i ekonomske nejednakosti trebaju biti tako uređene da su (a) od najveće očekivane koristi onima u najmanje povoljnom položaju i da su (b) pove-

\footnotetext{
${ }^{15}$ Prev. a., v. izvornik: »Each person is to have an equal right to the most extensive total system of equal basic liberties compatible with a similar system of liberty for all (Rawls, $A$ Theory of Justice..., 220).
} 
zane s položajima i službama koje su otvorene za sve pod uvjetima nepristranih jednakosti i mogućnosti«. ${ }^{16}$

Leksički poredak ovih dvaju temeljnih načela pravednosti teorijski je uspostavljen tako da jamči očuvanje samopoštovanja osoba, očuvanje njihovih sloboda, te time doprinosi stabilnosti društva. Nije naime moguće očuvati samopoštovanje osoba u najmanje povoljnom društvenom položaju, ako im nije maksimalno društveno moguće osiguran dohodovni minimum koji im omogućuje slobodan i jednak pristup javnim položajima i službama koje moraju biti nepristrano otvorene za sve osobe. U uvjetima društvenih nejednakosti u ekonomskim položajima građana, prvo načelo pravednosti ne može biti ostvareno bez ostvarenja drugog načela pravednosti. Omjeri ekonomskih nejednakosti za Rawlsa su zasigurno društvene varijable koje mogu ići u korist očuvanja stabilnosti društva putem očuvanja samopoštovanja osoba. Stoga je njegova socijalna filozofija s pravom nazvana filozofijom socijalnog liberalizma. Naime, za Rawlsa su nužne društvene konstante sloboda i demokracija. No što jamči i konstantan etički prioritet njegovim dvama temeljnim načelima pravednosti? Odgovor je, s obzirom na prethodno izneseno, jasan: Konstantan prioritet njegovim dvama temeljnim načelima pravednosti jamče smisleno neotklonjiva obilježja nepristranosti i jednakosti njihova fundamentalnog intuitivnog izvornika - inteligibilnog osjećaja za pravednost. Ova obilježja Rawlsova načela pravednosti svrstavaju u viši etički red.

\section{Zaključak}

U odnosu na problem intuicionizma usporedna analiza Rawlsovih stanovišta, iskazanih u njegovim glavnim djelima, pokazuje da u njima ne postoji proturječnost stajališta. Njegova kritika intuicionizma, uz istovremeno oslanjanje na intuiciju, samo je na prvi pogled proturječna. Naime, ona se poglavito odnosila na utilitarističke neposredne intuicije zdravorazumski prihvatljivih načela, a koje tijekom vremena, a bez oslonca na etički nedvojbeno utemeljenu teoriju, u praksi pokazuju simptome društvene heteronomičnosti uporabe. Rawlsovo oslanjanje na intuiciju je oslanjanje na inteligibilan osjećaj za pravednost kao ontološki izvornik njegovih načela pravednosti. Načela pravednosti, utemeljena na obilježjima nepristranosti i jednakosti kao na smisleno neotklonjivim obilježjima njihova ontološkog izvornika, onemogućuju bilo kakvu smislenu heteronomičnost njihove uporabe. Ova razlika jamči filozofski nedvojbeno i neproturječno utemeljen etički dio njegove teorijske konstrukcije društvenog ugovora. No prvenstveno svakako u okvirima etičkog fundacionalizma. Uspo-

\footnotetext{
${ }^{16}$ Prev. a., v. izvornik: » Social and economic inequalities are to be arranged so that they are both (a) to the greatest expected benefit of the least advantaged and (b) attached to offices and positions open to all under conditions of fair equality of opportunity« (isto, 72).
} 
redne analitičke naznake $\mathrm{u}$ odnosu na teorije pluralizma suvremenih moralnih doktrina pokazuju značajan stupanj teorijskog slaganja s Rawlsovim stajalištem o mogućnostima društvene prisutnosti i razvoja osjećaja za pravednost. Posebno kao demokratsku nužnost za mogućnost postizanja konsenzusa o temeljnim načelima društvenog funkcioniranja. Stoga su u etičkom smislu jedina suprotstavljena teorijska alternativa stanovištima sličnim Rawlsovom stajalištu zapravo samo redukcionističke teorije moralnog relativizma. Moralni relativizam svakako ima demokratsko i filozofsko pravo na svoja teorijska i praktička uporišta, kao i na svoje javne zagovornike. No ako se složimo s ovim relativističkim zagovaranjima, prethodno se neizostavno moramo složiti i s tim da priča o moralnosti doista dolazi do svoga skeptičkoga kraja. Naime, svaka intuicija o moralnosti ujedno je onda i intuicija o ne-moralnosti.

\section{Marko Jakić" \\ The problem of intuition of morality in John Rawl's philosophy \\ Summary}

The article deals with the possible view point paradox in John Rawls's philosophy. The introductory part critically outlines relevant contemporary theoretical views of the problem of the intuition of morality; with particular regard to direct intuitionism, relativism, and doctrinal moral pluralism. Rawls' theoretical position has been extracted in the central part of the article together with the arguments in support of the assertion of his theoretical position as a foundationalist indirect intuitionism. Additional arguments in support of Rawls' assertion of his principles of justice as the theoretical (ethical) higher principles have been analyzed. In conclusion, it has been shown that there is no view point paradox of the intuition of morality in his philosophy.

Key words: intuition, justice, fairness, equality, foundationalism.

(na engl. prev. Marko Jakić)

\footnotetext{
* Marko Jakić, PhD, assistant at the Department of Philosophy, University of Zadar, Address: Obala kralja Petra Krešimira IV., br. 2, HR-23000 Zadar, Croatia; E-mail: marko.jakic84@gmail. com.
} 